\title{
TELUR CACING KREMI
}

\section{Enterobius vermicularis, Oxyuris vermicularis, Pinworm}

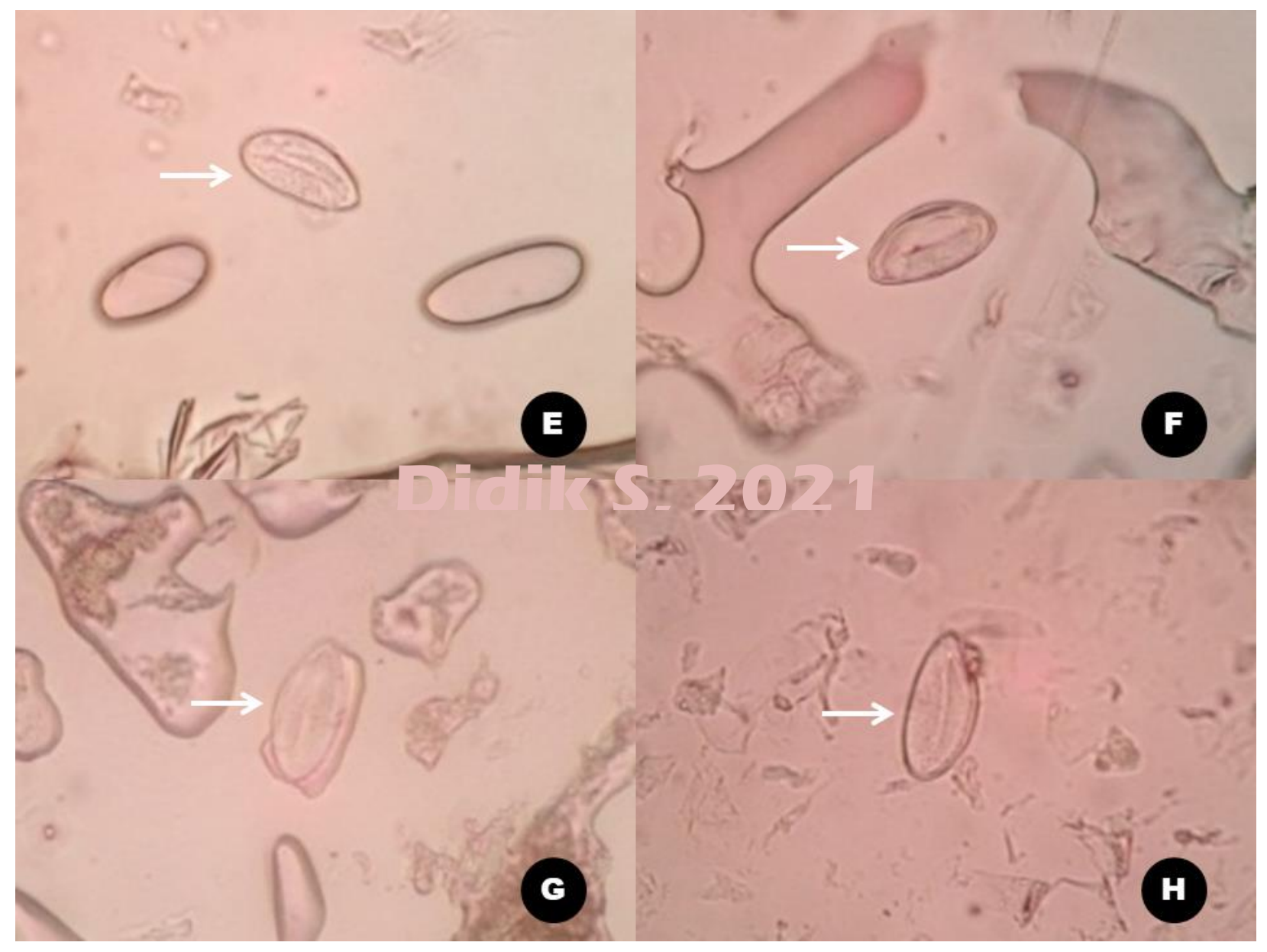

Telur Enterobius vermicularis dalam pengamatan mikroskopis pembesaran 40x obyektif. Preparat yang dibaca adalahsediaan telur dalam alat periplaswab sehingga tampak ada beberapa gelembung udara di sekitarnya. Telur cacing ada dalam tanda panah berwarna putih dengan bentuk khas oval asimetris dimana salah satu sisi dinding telurnya tampak relative mendatar. Dinding telur tipis transparan dari bahan hialin dan tesusun rangkap dua. Ke-empat gambar telur cacing diatas sudah berisi larva cacing yang khas. Lipatan badan larva di bagian tengah biasanya akan membentuk gambaran seperti garis yang sebenarnya adalah lipatan badan larva.

Didik S, 2021 